\title{
Autocrine control of vitamin D metabolism in synovial cells from arthritic patients
}

\author{
Susan J Smith, Michael E Hayes, Peter L Selby, E Barbara Mawer
}

\begin{abstract}
Objective-This study was designed to investigate whether 1,25-dihydroxyvitamin $D_{3}\left(1,25-(O H)_{2} D_{3}\right)$, produced by activated synovial fluid macrophages, promotes its own catabolism by upregulating vitamin D-24-hydroxylase (24OHase) in synovial fibroblasts through a vitamin D receptor (VDR) mediated mechanism.

Methods-Synovialmacrophages and fibroblasts were derived from patients with rheumatoid arthritis. Expression of VDR and 24-OHase mRNAs was determined using in situ hybridisation. Vitamin D hydroxylase activity was determined by incubating cells with $\left[{ }^{3} \mathrm{H}\right]-25-(\mathrm{OH}) \mathrm{D}_{3}$, or $\left[{ }^{3} \mathrm{H}\right]-1,25-(\mathrm{OH})_{2} \mathrm{D}_{3}$, and metabolite synthesis quantified using high performance liquid chromatography.

Results-1,25-(OH $)_{2} \mathrm{D}_{3}$ increased expression of mRNA for both VDR and 24OHase in fibroblasts by approximately threefold over 24 hours. 1,25-(OH) $)_{2} \mathrm{D}_{3}$ increased fibroblast 24-OHase activity, yielding 24-hydroxylated, and more polar, metabolites. In co-culture, fibroblasts were able to catabolise macrophage derived $1,25-(\mathrm{OH})_{2} \mathrm{D}_{3}$.

Conclusions-1,25-(OH $)_{2} \mathrm{D}_{3}$ is produced by macrophages in vitro at biologically relevant concentrations and can increase its own catabolism by synovial fibroblasts; this effect is probably mediated via upregulation of both synovial fibroblast VDR and 24-OHase.
\end{abstract}

(Ann Rheum Dis 1999;58:372-378)

The active metabolite of vitamin $\mathrm{D}_{3}, 1 \alpha, 25-$ dihydroxyvitamin $\mathrm{D}_{3}\left(1,25-(\mathrm{OH})_{2} \mathrm{D}_{3}\right)$, has immunoregulatory, pro-differentiating, and antiproliferative properties that have been shown to inhibit the progression of a number of autoimmune diseases, including experimental autoimmune encephalomyelitis ${ }^{1}$ and autoimmune diabetes. ${ }^{23} \mathrm{~A}$ recent paper by Cantorna et $a l^{4}$ has shown that $1,25-(\mathrm{OH})_{2} \mathrm{D}_{3}$ can both prevent the development and halt the progression of arthritis in murine models of the human disease. Oral 1,25- $(\mathrm{OH})_{2} \mathrm{D}_{3}$ treatment has also been shown to improve human psoriatic arthritis, ${ }^{5}$ and its analogue $1 \alpha$-hydroxyvitamin $\mathrm{D}_{3}$ inhibits type II collagen induced arthritis in rats. ${ }^{6}$

Exogenous administration of $1,25-(\mathrm{OH})_{2} \mathrm{D}_{3}$ may be a useful therapeutic approach for arthritis, however substrate dependent endogenous production of $1,25-(\mathrm{OH})_{2} \mathrm{D}_{3}$ can occur within the arthritic joint in vivo. ${ }^{78}$ The source of the extra-renal $1,25-(\mathrm{OH})_{2} \mathrm{D}_{3}$ is likely to be the synovial macrophage, as we have demonstrated in vitro that macrophages isolated from the synovial fluids of patients with inflammatory arthritis express vitamin-D-1 $\alpha-$ hydroxylase (1-OHase) activity, ${ }^{9}$ which can be regulated by locally encountered factors such as cytokines, for example, interferon gamma (IFN $\gamma$ ), bacterial lipopolysaccharide, and eicosanoids. ${ }^{10-14}$

Another vitamin D hydroxylase enzyme, namely the 24-hydroxylase (24-OHase), is responsible for the catabolism of 1,25$(\mathrm{OH})_{2} \mathrm{D}_{3}$, and is expressed by synovial fibroblasts. ${ }^{13} 1,25-(\mathrm{OH})_{2} \mathrm{D}_{3}$ and its receptor (VDR) bind to the vitamin $\mathrm{D}$ response elements (VDREs) of target genes to control their transcription and, as the promoter region of the human 24-OHase gene contains VDREs, ${ }^{15}$ it appears that the activity of the synovial fibroblast 24-OHase might be under the control of the local concentration of macrophage derived $1,25-(\mathrm{OH})_{2} \mathrm{D}_{3}$.

In this study we wanted to investigate how induction of synovial fibroblast 24-OHase by $1,25-(\mathrm{OH})_{2} \mathrm{D}_{3}$ may, in turn, regulate the local concentration of $1,25-(\mathrm{OH})_{2} \mathrm{D}_{3}$ in the synovial joint. In theory, this could be done via several mechanisms. Firstly, it may promote catabolism of existing $1,25-(\mathrm{OH})_{2} \mathrm{D}_{3}$ to $1,24,25$ trihydroxyvitamin $\mathrm{D}_{3}\left(1,24,25-(\mathrm{OH})_{3} \mathrm{D}_{3}\right)$, the start of the catabolic cascade for 1,25$(\mathrm{OH})_{2} \mathrm{D}_{3}$. While $1,24,25-(\mathrm{OH})_{3} \mathrm{D}_{3}$ has some biological activity, it is less potent than the precursor $1,25-(\mathrm{OH})_{2} \mathrm{D}_{3} \cdot{ }^{16}$ Secondly, the 24OHase may lessen the pool of precursor $25-(\mathrm{OH}) \mathrm{D}_{3}$ available to macrophages for 1-hydroxylation (which is known to be substrate dependent), by diverting $25-(\mathrm{OH}) \mathrm{D}_{3}$ into the synthesis of 24,25-dihydroxyvitamin $\mathrm{D}_{3}\left(24,25-(\mathrm{OH})_{2} \mathrm{D}_{3}\right)$. An increase in 24,25$(\mathrm{OH})_{2} \mathrm{D}_{3}$ concentration may itself provide a third mechanism to reduce entry of freshly synthesised $1,25-(\mathrm{OH})_{2} \mathrm{D}_{3}$ into the system; we have demonstrated that $24,25-(\mathrm{OH})_{2} \mathrm{D}_{3}$ can be converted to $1,24,25-(\mathrm{OH})_{3} \mathrm{D}_{3}$ by synovial fluid macrophages (unpublished data), and will therefore compete with $25-(\mathrm{OH}) \mathrm{D}_{3}$ as a substrate for 1-hydroxylation.

If $1,25-(\mathrm{OH})_{2} \mathrm{D}_{3}$ (or one of its analogues) is to be used therapeutically for inflammatory arthropathies it is important to understand its breakdown in vivo, firstly for the administration of an effective dose and secondly to ensure that the concentration of $1,25-(\mathrm{OH})_{2} \mathrm{D}_{3}$ can be controlled locally, thus preventing unwanted systemic side effects and possible juxtaarticular osteoporosis. The aim of this study was to investigate further the regulation of the 
synovial fibroblast $24-\mathrm{OH}$ ase by $1,25-(\mathrm{OH})_{2} \mathrm{D}_{3}$ in vitro, at both the molecular and functional level, and to determine whether this effect is mediated via VDR. Expression of synovial fibroblast VDR and 24-OHase mRNAs was determined using in situ hybridisation. The effects of exposure to $1,25-(\mathrm{OH})_{2} \mathrm{D}_{3}$ on the metabolism of $\left[{ }^{3} \mathrm{H}\right]-25-(\mathrm{OH}) \mathrm{D}_{3}$ and $\left[{ }^{3} \mathrm{H}\right]-$ $1,25-(\mathrm{OH})_{2} \mathrm{D}_{3}$ by synovial fibroblasts, and the effects of fibroblasts on the metabolism of $1,25-(\mathrm{OH})_{2} \mathrm{D}_{3}$ produced by macrophages when the two cell types were co-cultured, were also investigated using a hydroxylase assay.

\section{Methods}

SOURCE OF SYNOVIAL CELLS

Synovial fibroblasts (designated F733), derived from an explant culture from a patient with rheumatoid arthritis, were kindly supplied by Dr David Taylor. Cells were routinely grown in Dulbecco's modified Eagle's medium (DMEM) containing $1 \times 10^{-3} \mathrm{M}$ sodium pyruvate (Gibco), $2 \times 10^{-3} \mathrm{M} \mathrm{L}$-glutamine, $50 \mathrm{IU} / \mathrm{ml}$ penicillin, $50 \mu \mathrm{g} / \mathrm{ml}$ streptomycin, and $10 \% \mathrm{v} / \mathrm{v}$ fetal bovine serum (Imperial) and passaged every $1-2$ weeks using $0.25 \%$ trypsin, $0.02 \%$ w/v EDTA in phosphate buffered saline (Imperial). Cells were used at passage 10 in these experiments.

A primary culture of synovial fluid macrophages was established from the synovial fluid of a patient with rheumatoid arthritis using the method of Hayes et al. ${ }^{12}$ Briefly, the synovial fluid sample was diluted in RPMI-1640 culture medium containing $2 \% \mathrm{v} / \mathrm{v}$ fetal bovine serum, $4 \times 10^{-4} \mathrm{M} \mathrm{L}$-glutamine, $10 \mathrm{IU} / \mathrm{ml}$ penicillin, and $10 \mu \mathrm{g} / \mathrm{ml}$ streptomycin. From experience, we have found that incubating the sample in $2 \% \mathrm{v} / \mathrm{v}$ fetal bovine serum, rather than $10 \% \mathrm{v} / \mathrm{v}$ fetal bovine serum, encourages the culture of macrophages, but not fibroblasts, thus allowing fibroblast free cultures of macrophages to be established. Any macrophage culture contaminated by fibroblasts can be readily identified, because fibroblasts proliferate in culture and can be seen as colonies.

The sample was incubated at $37^{\circ} \mathrm{C}$ in a humidified atmosphere of air with $5 \%$ carbon dioxide for 2-3 days; after this time macrophages had adhered to the culture plate surface and non-adherent cells were washed away. All cells from the sample stained positive for nonspecific esterase activity, a marker of monocyte-macrophages.

DETERMINATION OF MRNA EXPRESSION USING IN SITU HYBRIDISATION

F733 cells were pre-treated for five or 24 hours with $5 \times 10^{-8} \mathrm{M} 1,25-(\mathrm{OH})_{2} \mathrm{D}_{3}$ (Hoffman La Roche) or vehicle $(0.125 \% \mathrm{v} / \mathrm{v}$ ethanol) in glass chamber slides (Lab-Tek) and fixed in $10 \% \mathrm{v} / \mathrm{v}$ formaldehyde. Expression of VDR and 24OHase mRNA was determined using in situ hybridisation with $\left[{ }^{35} \mathrm{~S}\right]$ labelled riboprobes. The $2.1 \mathrm{~kb}$ human VDR cDNA probe was kindly supplied by Dr G Williams already subcloned into the ampicillin resistant plasmid pBluescript II KS (Stratagene). The $1.8 \mathrm{~kb}$ partial length human 24-OHase cDNA probe was kindly supplied by Drs J Omdahl and B
May, cloned into the Pst I site of Bluescript $\mathrm{KS}+$. The in situ hybridisation technique used in this study has previously been described by Mee et al. ${ }^{17}$ Controls were sense riboprobe and RNase A treated cells (Sigma; $1 \mathrm{mg} / \mathrm{ml}$ in water for one hour at $37^{\circ} \mathrm{C}$ ) to ensure that probe binding to cells was RNA specific. Probe hybridisation was detected by dipping slides in photographic emulsion (Ilford K5) diluted 1:1 with distilled water and developed after seven days at $4^{\circ} \mathrm{C}$. The radiation produces silver grains within the emulsion that can be visualised as "black dots" and, as the path length of $\left[{ }^{35} \mathrm{~S}\right]$ is $15-20 \mu \mathrm{m}$, the positions of the black dots localise the areas of probe binding. Cells were counterstained using eosin and Harris haematoxylin and examined using light field microscopy. Probe hybridisation was quantified with a Quantimet 600 image analyser linked to a Leica DM microscope (Leica UK Ltd), ${ }^{18}$ allowing the percentage cell area covered by silver grains to be calculated, corrected for background levels of probe binding.

DETERMINATION OF VITAMIN D HYDROXYLASE ACTIVITY

Effect of $1,25-(\mathrm{OH})_{2} \mathrm{D}_{3}$ on synovial fibroblast vitamin $D$ hydroxylase activity

To study the effects of $1,25-(\mathrm{OH})_{2} \mathrm{D}_{3}$ on F733 vitamin $\mathrm{D}$ hydroxylase activity, cells were pre-treated with $1,25-(\mathrm{OH})_{2} \mathrm{D}_{3}\left(10^{-7}\right.$ to $10^{-11}$ $\mathrm{M}$ ), or vehicle (ethanol, $0.25 \% \mathrm{v} / \mathrm{v}$ ), in DMEM containing $6.25 \mu \mathrm{g} / \mathrm{ml}$ insulin, $6.25 \mu \mathrm{g} / \mathrm{ml}$ transferrin, $6.25 \mathrm{ng} / \mathrm{ml}$ selenous acid, $1.25 \mathrm{mg} / \mathrm{ml}$ bovine serum albumin (BSA), $5.35 \mu \mathrm{g} / \mathrm{ml}$ linoleic acid (ITS ${ }^{+}$; Becton Dickinson), $2 \times 10^{-3} \mathrm{M}$ L-glutamine, $50 \mathrm{IU} / \mathrm{ml}$ penicillin, and $50 \mu \mathrm{g} / \mathrm{ml}$ streptomycin. Cells were incubated for 24 hours in a humidified atmosphere of $95 \%$ air, $5 \%$ carbon dioxide, then washed and left for three hours in ITS $^{+}$supplemented DMEM; this allowed time for any pre-treatment 1,25$(\mathrm{OH})_{2} \mathrm{D}_{3}$ to be metabolised by cells before incubation with substrate. Enzyme activity was then determined by incubating cells for 1.5 hours in fresh DMEM containing either $25-(\mathrm{OH}) \mathrm{D}_{3}$ or $1,25-(\mathrm{OH})_{2} \mathrm{D}_{3}(358 \mathrm{pg} / \mathrm{ml}$ and $43.5 \mathrm{pg} / \mathrm{ml}$ respectively), supplemented with $5 \times$ $10^{4} \mathrm{dpm}$ tritiated substrate (25-hydroxy $\left[26,(27)-\right.$ methyl $\left.-{ }^{3} \mathrm{H}\right]$ cholecalciferol $\left(\left[{ }^{3} \mathrm{H}\right]-25-\right.$ $\left.(\mathrm{OH}) \mathrm{D}_{3}\right)$, specific activity about $15.0 \mathrm{Ci} / \mathrm{mmol}$ or 1 $\alpha, 25$-dihydroxy [26,27-methyl- $\left.{ }^{3} \mathrm{H}\right]$ cholecalciferol $\left(\left[{ }^{3} \mathrm{H}\right]-1,25-(\mathrm{OH})_{2} \mathrm{D}_{3}\right)$, specific activity about $173 \mathrm{Ci} / \mathrm{mmol}$; Amersham) $0.5 \%$ v/v BSA (Orthodiagnostic Systems Ltd) and $2 \times 10^{-3} \mathrm{M}$ L-glutamine, using the hydroxylase assay described previously by Hayes et al. ${ }^{12}$ A blank incubation (no cells) was also included in the assay. Metabolites were extracted using chloroform: methanol, 3:2 v/v and quantified using high performance liquid chromatography (HPLC) and liquid scintillation counting. Briefly, the chloroform layer was extracted and analysed on a manual injection normal phase HPLC system developed with a mobile phase of n-hexane:isopropanol:methanol, 115:3.3:4 (v/v) at $2 \mathrm{ml} / \mathrm{min}$ and a Zorbax-Sil column $(4.6 \mathrm{~mm} \times 25 \mathrm{~cm})$. Eluant fractions were collected, the radioactivity measured, and the 

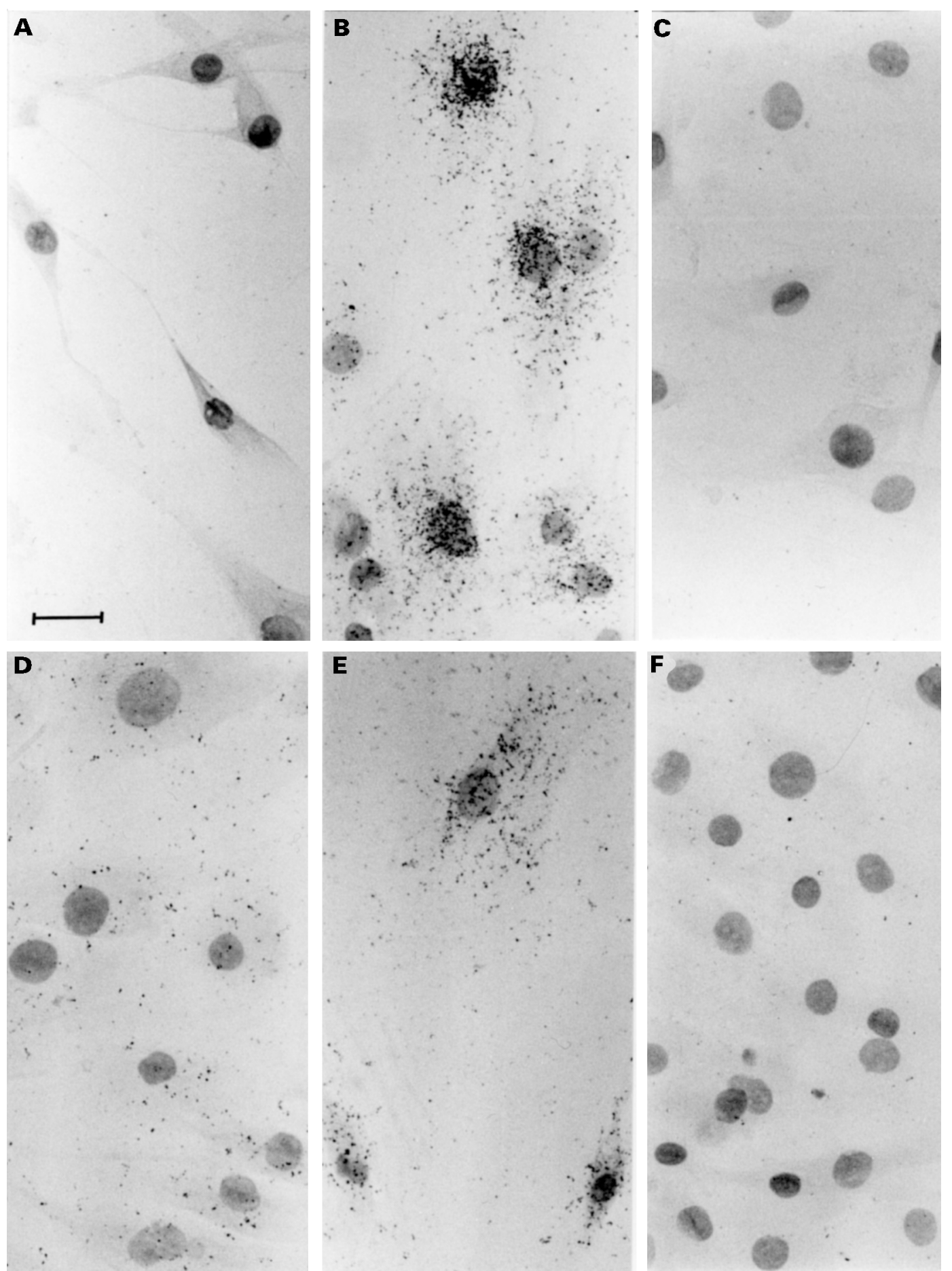

Figure 1 Photomicrographs showing hybridisation of ${ }^{35} S$ J labelled riboprobe for 24-OHase and VDR mRNAs in F733 synovial fibroblasts. F733 cells were pre-treated with $5 \times 10^{-8} \mathrm{M} 1,25-(\mathrm{OH})_{2} \mathrm{D}_{3}$, or vehicle $(0.125 \%$ v/v ethanol), fixed, then hybridised overnight with ${ }^{5} S$ S labelled riboprobe for 24-OHase or VDR $m R N A$. (A) Twenty four hour vehicle treated cells, 24-OHase probe; (B) 24 hour 1,25-(OH) ${ }_{2} D_{3}$ treated cells, 24-OHase probe; (C) RNase A treated control slide, 24-OHase probe; (D) 24 hour vehicle treated cells, VDR probe; (E) 24 hour 1,25-(OH) ${ }_{2} D_{3}$ treated cells, VDR probe; (F) RNase A treated control slide, VDR probe. Bar $=50 \mu \mathrm{m}$, cells counterstained with eosin and Harris haematoxylin (Sigma).

known specific activity of substrate used to calculate the rate of synthesis of vitamin $\mathrm{D}_{3}$ metabolites in each sample. An aliquot of the upper aqueous phase of the extraction mixture was also counted as a measure of more polar metabolites.

\section{Synovial macrophages and fibroblasts in co-culture}

A co-culture system was established to determine whether synovial macrophage derived $1,25-(\mathrm{OH})_{2} \mathrm{D}_{3}$ could be directly 24-

hydroxylated by F733 in vitro to form 1,24,25$(\mathrm{OH})_{3} \mathrm{D}_{3} . \mathrm{F} 733$ were grown in sterile $12 \mathrm{~mm}$ diameter polystyrene well inserts (Costar), which could fit into the wells of a 12 well tissue culture dish (Corning) in which the macrophages were cultured. The inserts had a $3.0 \mu \mathrm{m}$ porous membrane that allowed the culture medium to move freely between the chambers. Adequate synthesis of $1,25-(\mathrm{OH})_{2} \mathrm{D}_{3}$ by macrophages was ensured by pre-treatment for 24 hours with $5 \times 10^{-9} \mathrm{M}$ interferon gamma (IFN $\gamma$; Advanced Protein Products Ltd). After 

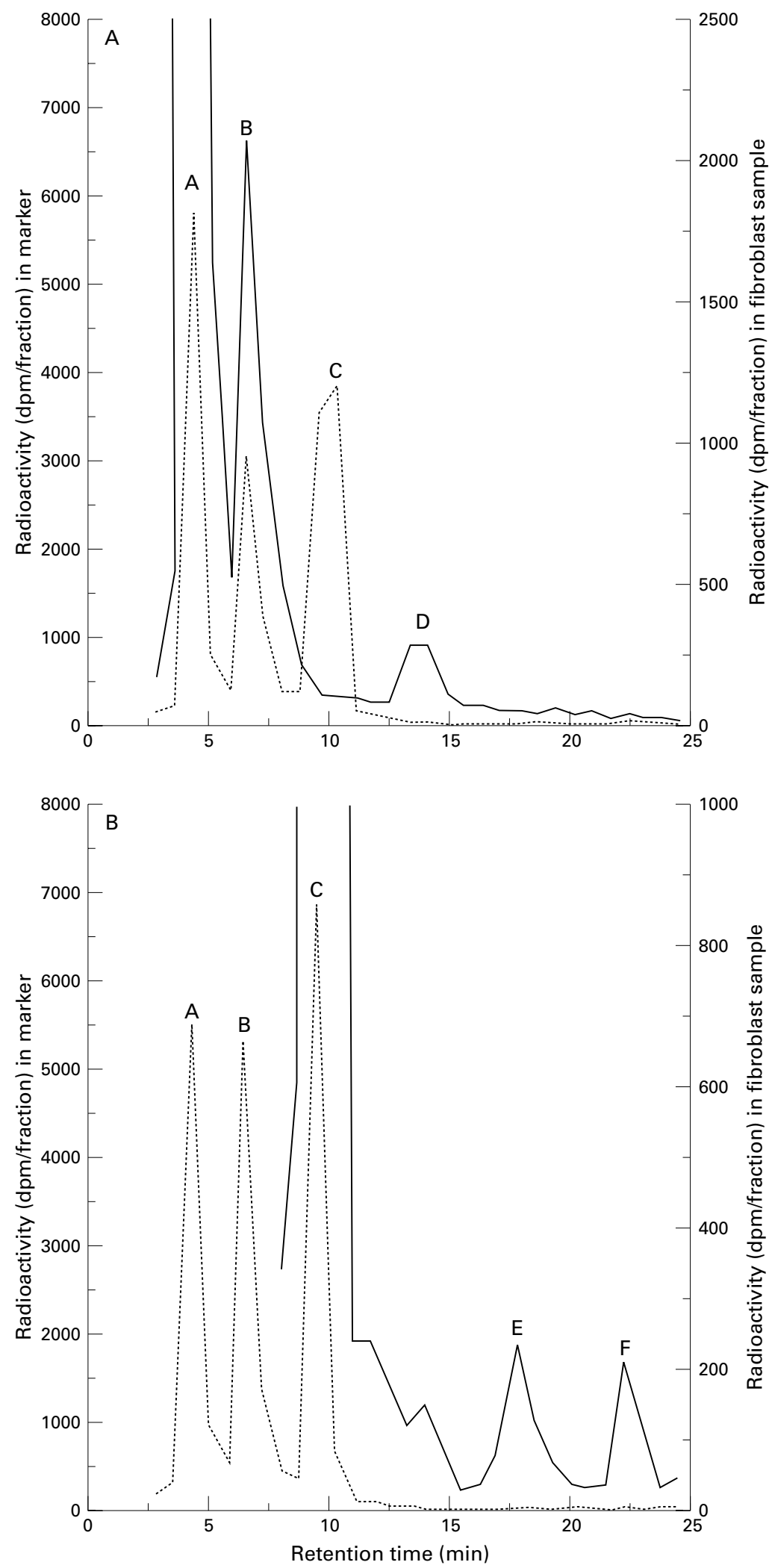

Figure 2 HPLC profile of synovial fluid fibroblast $(A)\left[{ }^{3} \mathrm{H}\right]-25-(\mathrm{OH}) \mathrm{D}_{3}$ and $(\mathrm{B})$ $[\mathrm{H}]-1,25-(\mathrm{OH}) \mathrm{D}$ metabolism. HPLC conditions are as described in Methods. The dotted traces show the positions of known tritiated forms of 25-(OH) $\mathrm{D}_{3}$ (peak $\mathrm{A}$ ), 24,25-(OH) ${ }_{2} D_{3}$ (peak B), and 1,25-(OH) ${ }_{2} D_{3}$ (peak $\left.C\right)$. As no radioactive tracer was available, the expected position of a tritiated 1,24,25-(OH) ${ }_{3} D_{3}$ peak was calculated using an ultraviolet trace of unlabelled markers in conjunction with the radioactive trace above. The solid trace in figure 2 (A) shows the metabolism of substrate [ $\left.{ }^{3} \mathrm{H}\right]-25-(\mathrm{OH}) \mathrm{D}_{3}$ to its 24-hydroxylated form, $\left.{ }^{3} \mathrm{H}\right]-24,25-(\mathrm{OH})_{2} \mathrm{D}_{3}$, by synovial fluid fibroblasts pre-treated for 24 hours with $10^{-8}$ $M 1,25-(\mathrm{OH}){ }_{2} D_{3}$. The position of an unidentified product, which was more polar than $\left.{ }^{3} \mathrm{H}\right]-24,25-(\mathrm{OH})_{2}^{2} \mathrm{D}_{3}$, is indicated by peak $D$. The solid trace in figure 2 (B) shows the metabolism of substrate $\left.{ }^{3} \mathrm{H}\right]-1,25-(\mathrm{OH})_{2} \mathrm{D}_{3}$ by synovial fluid fibroblasts pre-treated for 24 hours with $10^{-11} \mathrm{M} 1,25-(\mathrm{OH}){ }_{2} \mathrm{D}_{3}$. A metabolite with an elution time representing that of $\left[{ }^{3} H\right]-1,24,25-(\mathrm{OH})_{3} D_{3}$ is shown by peak $E$ and the position of an unidentified product, which was more polar than $\left[{ }^{3} \mathrm{H}\right]-1,24,25-(\mathrm{OH})_{3} D_{3}$, is indicated by peak $\mathrm{F} ; \mathrm{dpm}=$ disintegrations per minute. pre-treatment, macrophages were washed once with basal medium, then incubated alone or in combination with F733 for a further 24 hours with $\left[{ }^{3} \mathrm{H}\right]-25-(\mathrm{OH}) \mathrm{D}_{3}(12.5 \mathrm{ng} / \mathrm{ml})$ using the hydroxylase assay described above.

STATISTICS

Statistical analysis of results was carried out with Instat for MacIntosh (version 2.01), using analysis of variance (ANOVA) and Student's $t$ test. Non-normally distributed data were log transformed before analysis.

\section{Results}

REGULATION OF 24-OHASE AND VDR mRNAS BY $1,25-(\mathrm{OH})_{2} \mathrm{D}_{3}$ IN F733 SYNOVIAL FIBROBLASTS 24-OHase mRNA (fig $1(A-C)$ )

Pre-treatment with $1,25-(\mathrm{OH})_{2} \mathrm{D}_{3}$ for either five or 24 hours increased probe binding to F733, indicating an increase in 24-OHase mRNA. At both time points some cells had very high activity while others had very low activity, possibly because of differences in the state of cell differentiation or cell cycle, or both. The extent of hybridisation was quantified and expressed as the \% cell area covered by silver grains. There was a significant increase in probe binding $(\mathrm{p}<0.01)$ from $2.3(0.5) \%$ (mean (SEM)) in cells treated with vehicle for five hours to $6.2(1.0) \%$ in cells treated with $1,25-(\mathrm{OH})_{2} \mathrm{D}_{3}$ for five hours (results not shown). There was a similar increase in probe binding ( $\mathrm{p}<0.05)$ from $1.7(0.3) \%$ in cells treated with vehicle for 24 hours fig $1(\mathrm{~A})$ ) to $5.1(2.2) \%$ in cells treated with $1,25-(\mathrm{OH})_{2} \mathrm{D}_{3}$ for 24 hours (fig 1(B)). Both RNase A treated control slides (fig 1(C)) and sense riboprobe control slides showed only background levels of silver grains.

$V D R$ mRNA (fig $1(D-F))$

There was an increase in probe binding to F733 cells after 24 hours of $5 \times 10^{-8} \mathrm{M}$ $1,25-(\mathrm{OH})_{2} \mathrm{D}_{3}$ treatment, but not after five hours. Percentage silver grain density for five hour vehicle, five hour $1,25-(\mathrm{OH})_{2} \mathrm{D}_{3}$ treated cells, and 24 hour vehicle were $1.4(0.2) \%, 1.5$ $(0.3) \%$, and $1.5(0.2) \%$ respectively. Binding after 24 hour $1,25-(\mathrm{OH})_{2} \mathrm{D}_{3}$ pre-treatment $(4.5$ $(0.5) \%$; fig $1(\mathrm{E})$ ) was significantly increased compared with the 24 hour vehicle (fig 1(D); p $<0.01$ ) and five hour treatment values $(\mathrm{p}<$ 0.01). Again, both RNase A treated control slides (fig $1(\mathrm{~F})$ and sense riboprobe control slides showed only background levels of silver grains.

EXPRESSION OF VITAMIN D HYDROXYLASE ACTIVITY (FROM HYDROXYLASE ASSAYS) Metabolism of [ $\left.{ }^{\beta} \mathrm{H}\right]-25-(\mathrm{OH}) \mathrm{D}_{3}$ by synovial fibroblasts pre-treated with 1,25-(OH) ${ }_{2} \mathrm{D}_{3}$ The HPLC trace in fig 2(A) shows the typical metabolism of $\left[{ }^{3} \mathrm{H}\right]-25-(\mathrm{OH}) \mathrm{D}_{3}$ (peak A) to $\left[{ }^{3} \mathrm{H}\right]-24,25-(\mathrm{OH})_{2} \mathrm{D}_{3}$ (peak $\left.\mathrm{B}\right)$ and an unidentified metabolite (peak D) by F733 cells pre-treated for 24 hours with $10^{-8} \mathrm{M} \mathrm{1,25-}$ $(\mathrm{OH})_{2} \mathrm{D}_{3}$. Fig 3 (A) shows that synthesis of $\left[{ }^{3} \mathrm{H}\right]-24,25-(\mathrm{OH})_{2} \mathrm{D}_{3}$ was increased in a dose dependent manner by increasing pre-treatment concentrations of $1,25-(\mathrm{OH})_{2} \mathrm{D}_{3}$, with a mean 

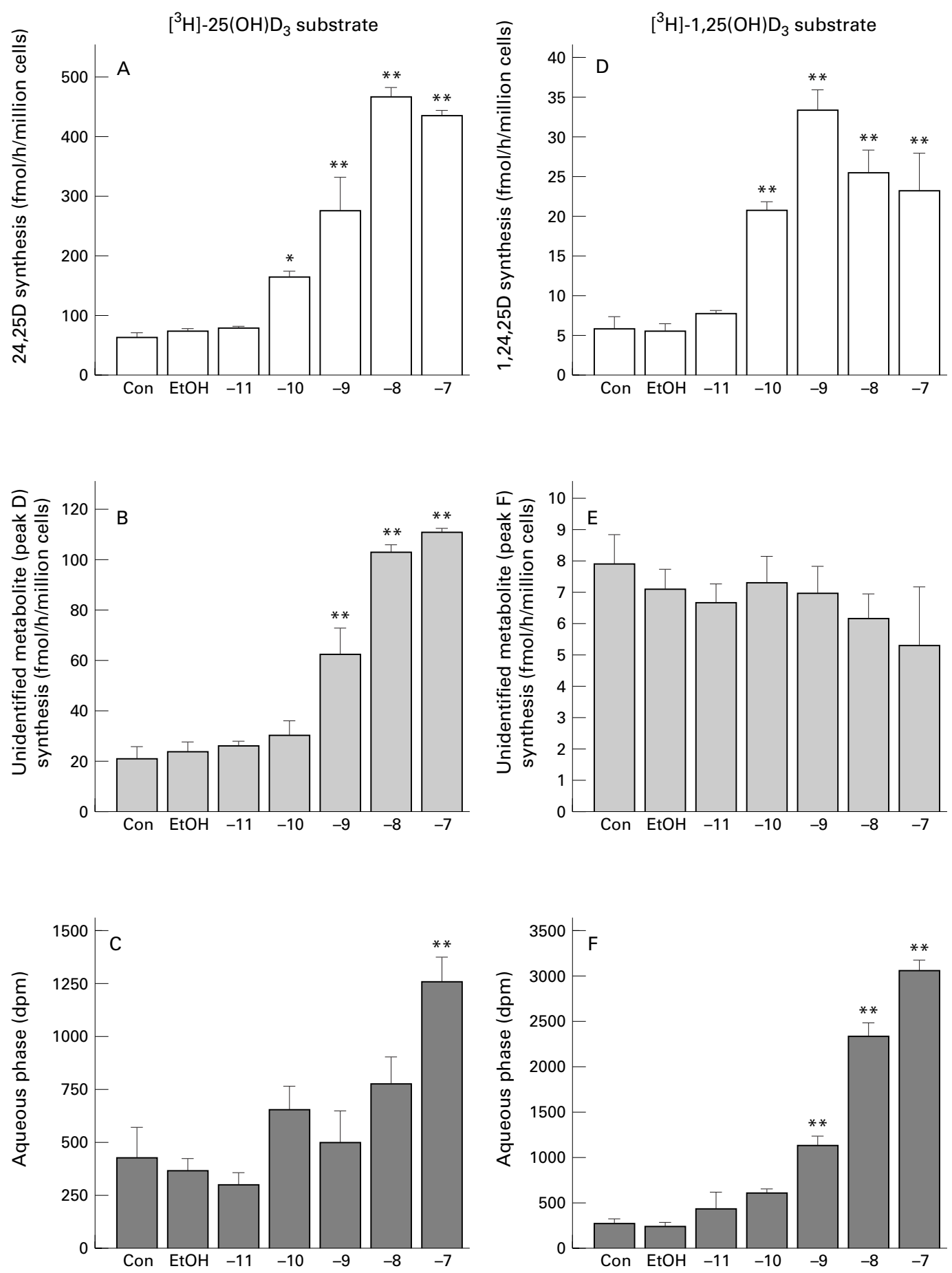

24 hour 1,25D pre-treatment $(\log 10 \mathrm{M})$

24 hour 1,25D pre-treatment $(\log 10 \mathrm{M})$

Figure 3 Effects of 1,25- $(\mathrm{OH})_{2} \mathrm{D}_{2}$ pre-treatment on the metabolism of $\left.{ }^{3} \mathrm{H}\right]-25-(\mathrm{OH}) \mathrm{D}_{3}$ and $\left.{ }^{3} \mathrm{H}\right]-1,25-(\mathrm{OH})_{2} \mathrm{D}_{3}$ by F733 synovial fibroblasts. Panels $(A-C)$ are cells incubated with $[H]-25-(O H) D$ substrate, panels $(D-F)$ are cells incubated with $\beta \mathrm{H}]-1,25-(\mathrm{OH})_{2} \mathrm{D}_{3}$ substrate. (A) Synthesis of $\left.{ }^{\beta} \mathrm{H}\right]-24,25-(\mathrm{OH})_{2} \mathrm{D}_{3} ;(B)$ synthesis of an unidentified product (peak $D$ in fig $2(A)$ ); (C) the radioactivity present in the aqueous phase; (D) synthesis of

$\left[{ }^{3} \mathrm{H}\right]-1,24,25-(\mathrm{OH})_{3} D_{3} ;(E)$ synthesis of an unidentified product (peak $F$ in figure $2(B)$ ) and $(F)$ radioactivity present in the aqueous phase. $n=3$ for each point. Results are shown as mean $(S E M) .{ }^{*} p<0.05,{ }^{\star *} p<0.01$ compared with vehicle (0.25\% ethanol) using ANOVA followed by Dunnett's multiple comparison test.

(SEM) of $73.8(5.3) \mathrm{fmol} / \mathrm{h} / 10^{6}$ cells in controls (vehicle treated), and maximum activity of 463.1 (14.6) $\mathrm{fmol} / \mathrm{h} / 10^{6}$ cells in $10^{-8} \mathrm{M}$ pre-treated cells $(\mathrm{p}<0.01)$. The unidentified metabolite (peak D in figures $2(\mathrm{~A})$, and $3(\mathrm{~B})$ ), which was more polar than $24,25-(\mathrm{OH})_{2} \mathrm{D}_{3}$, was also synthesised in a dose dependent manner, and was not present in blank (no cells) samples, indicating this is a metabolite and not an incubation artefact. This metabolite was not 25,26-dihydroxyvitamin $\mathrm{D}_{3}$, which elutes be- tween $24,25-(\mathrm{OH})_{2} \mathrm{D}_{3}$ and $1,25-(\mathrm{OH})_{2} \mathrm{D}_{3}$ in our solvent system.

An aliquot of the aqueous phase was added to scintillation cocktail and $\left[{ }^{3} \mathrm{H}\right] \mathrm{dpm}$ measured. The unidentified radioactivity present in the aqueous phase of the extraction mixture (corrected from the blank (no cells) incubation) increased with $1,25-(\mathrm{OH})_{2} \mathrm{D}_{3}$ pretreatment concentration (fig 3 (C)). This radioactivity indicates the presence of more polar products than those found in the chloro- 
Table 1 Metabolism of [ $\left.{ }^{3} \mathrm{H}\right]-25-(\mathrm{OH}) \mathrm{D}_{3}$ by synovial fibroblasts and macrophages incubated separately and in co-culture

\begin{tabular}{lllll}
\hline \multicolumn{4}{c}{ Metabolite synthesis (pmol/incubation/24 h) } \\
\cline { 2 - 3 } Cell type & $24,25-(\mathrm{OH})_{2} \mathrm{D}_{3}$ & $1,25-(\mathrm{OH})_{2} \mathrm{D}_{3}$ & $1,24,25-(\mathrm{OH})_{3} \mathrm{D}_{3}$ & $\begin{array}{l}\text { Aqueous } \\
\text { phase }\end{array}$ \\
\hline Macrophages (untreated) & $\mathrm{nd}$ & $12.1(4.6)$ & $\mathrm{nd}$ & $1.5(0.1)$ \\
IFN $\gamma$ pre-treated macrophages & $\mathrm{nd}$ & $34.6(3.0)$ & $1.3(0.5)$ & $1.3(0.3)$ \\
F733 (untreated) & $10.9(0.8)$ & nd & nd & $0.7(0.1)$ \\
Co-culture & $7.1(0.2)$ & $12.4(0.3)$ & $6.7(0.0)$ & $5.4(0.2)$ \\
\end{tabular}

Results are expressed as mean $(\mathrm{SEM}), \mathrm{n}=3$; nd=none detected. The co-culture incubation consisted of F733 (untreated) and IFN $\gamma$ pre-treated macrophages.

form layer, however the number and nature of metabolites present in the aqueous phase was not determined.

Metabolism of [ $\left.{ }^{3} \mathrm{H}\right]-1,25-(\mathrm{OH})_{2} \mathrm{D}_{3}$ by synovial fibroblasts pre-treated with $1,25-(\mathrm{OH})_{2} \mathrm{D}_{3}$

The HPLC trace in figure 2 (B) shows the typical metabolism of $\left[{ }^{3} \mathrm{H}\right]-1,25-(\mathrm{OH})_{2} \mathrm{D}_{3}$ (peak C) to $\left[{ }^{3} \mathrm{H}\right]-1,24,25-(\mathrm{OH})_{3} \mathrm{D}_{3}$ (peak E) and an unidentified metabolite (peak F) by F733 pre-treated for 24 hours with $10^{-11} \mathrm{M}$ $1,25-(\mathrm{OH})_{2} \mathrm{D}_{3}$. As no radioactive tracer was available for $1,24,25-(\mathrm{OH})_{3} \mathrm{D}_{3}$, a=n ultraviolet absorbance trace of unlabelled 1,24,25$(\mathrm{OH})_{3} \mathrm{D}_{3}$ was used as a marker. $1,25-(\mathrm{OH})_{2} \mathrm{D}_{3}$ pre-treatment led to an increase in putative $\left[{ }^{3} \mathrm{H}\right]-1,24,25-(\mathrm{OH})_{3} \mathrm{D}_{3}$ synthesis (fig 3 (D)) with a mean (SEM) of $5.6(0.9) \mathrm{fmol} / \mathrm{h} / 10^{6}$ cells in vehicle treated control cells $(0.25 \% \mathrm{v} / \mathrm{v}$ ethanol) to $33.3(2.7) \mathrm{fmol} / \mathrm{h} / 10^{6}$ cells in $10^{-9} \mathrm{M}$ treated cells $(\mathrm{p}<0.01)$. The concentration of $\left[{ }^{3} \mathrm{H}\right]-1,24,25-(\mathrm{OH})_{3} \mathrm{D}_{3}$ peaked with $10^{-9} \mathrm{M}$ $1,25-(\mathrm{OH})_{2} \mathrm{D}_{3}$ pre-treatment and declined at $10^{-8} \mathrm{M}$ and $10^{-7} \mathrm{M}$. It is possible that the cells pre-treated with these higher concentrations of $1,25-(\mathrm{OH})_{2} \mathrm{D}_{3}$ had started to metabolise $\left[{ }^{3} \mathrm{H}\right]-$ $1,24,25-(\mathrm{OH})_{3} \mathrm{D}_{3}$ to further catabolic products, which would explain the much higher counts in the aqueous phase seen with these two treatment points (fig $3(\mathrm{~F})) \cdot 1,25-(\mathrm{OH})_{2} \mathrm{D}_{3}$ pre-treatment had no significant effect on the synthesis of the unidentified more polar metabolite (peak F in fig 2 (B), and fig $3(\mathrm{E})$ ).

Vitamin D metabolism in synovial macrophages and fibroblasts in co-culture

Table 1 shows the rates of $\left[{ }^{3} \mathrm{H}\right]$-vitamin $\mathrm{D}_{3}$ metabolite synthesis by synovial fluid macrophages and fibroblasts alone and in co-culture. F733 cells synthesised $24,25-(\mathrm{OH})_{2} \mathrm{D}_{3}$ while macrophages synthesised $1,25-(\mathrm{OH})_{2} \mathrm{D}_{3}$. IFN $\gamma$ stimulated macrophages synthesised increased levels of $1,25-(\mathrm{OH})_{2} \mathrm{D}_{3}$ and a small quantity of putative $1,24,25-(\mathrm{OH})_{3} \mathrm{D}_{3}$ - possibly because of induction of macrophage 24-OHase activity when local $1,25-(\mathrm{OH})_{2} \mathrm{D}_{3}$ levels were high. The co-culture of F733 and IFN $\gamma$ stimulated macrophages showed synthesis of $1,25-(\mathrm{OH})_{2} \mathrm{D}_{3}$, $24,25-(\mathrm{OH})_{2} \mathrm{D}_{3}$ and $1,24,25-(\mathrm{OH})_{3} \mathrm{D}_{3}$. There were also increased concentrations of $\left[{ }^{3} \mathrm{H}\right]$ metabolites in the aqueous phases of the co-culture incubations than in cells incubated separately $(\mathrm{p}<0.001)$.

\section{Discussion}

We have demonstrated previously that 1,25$(\mathrm{OH})_{2} \mathrm{D}_{3}$ may be synthesised locally within the arthritic joint ${ }^{8}$ and have studied the regulation of synovial macrophage 1-OHase activity in vitro. $^{9-14}$ We have now extended these observations to show that, in vitro at least, fibroblasts of synovial origin can regulate the local 1,25$(\mathrm{OH})_{2} \mathrm{D}_{3}$ concentration at or near its site of synthesis. Moreover, this mechanism is regulated in a dose dependent fashion by $1,25-$ $(\mathrm{OH})_{2} \mathrm{D}_{3}$ itself, acting in a paracrine mode, with a significant effect seen at near physiological concentrations $\left(10^{-10} \mathrm{M}\right)$. The stimulatory effects of $1,25-(\mathrm{OH})_{2} \mathrm{D}_{3}$ on synovial fibroblast 24-OHase activity may be mediated via stimulation of both 24-OHase and VDR gene transcription, or by increasing mRNA stability, with increased mRNAs at five hours and 24 hours respectively. Initial upregulation of 24OHase activity may be sufficient to catabolise raised local $1,25-(\mathrm{OH})_{2} \mathrm{D}_{3}$ levels, however if supraphysiological concentrations of 1,25$(\mathrm{OH})_{2} \mathrm{D}_{3}$ persist, an increase in VDR mRNA and protein may be required to increase the clearance rate.

We have previously studied the effect of $1,25-(\mathrm{OH})_{2} \mathrm{D}_{3}$ on 24-OHase activity and mRNA in a variety of rheumatoid synovial fibroblast cell lines, and on the same lines at different passage numbers, and always found a stimulatory effect on both 24-hydroxylase and mRNA levels - so much so, that fibroblast cell lines are used as reliable positive controls in house for the in situ hybridisation method. We have not studied fibroblasts from osteoarthritic synovium, however it would be interesting to see if there were differences in the expression of these molecules in the different disease states, particularly as we have previously shown a difference in endogenous $1,25-(\mathrm{OH})_{2} \mathrm{D}_{3}$ synthesis in rheumatoid and osteoarthritis. ${ }^{8}$

Once the stimulatory effect of exogenous $1,25-(\mathrm{OH})_{2} \mathrm{D}_{3}$ on fibroblast 24-OHase had been established, we examined the metabolism of $25-(\mathrm{OH}) \mathrm{D}_{3}$ by macrophages and fibroblasts in co-culture. We have now demonstrated that synovial fibroblasts can metabolise macrophage derived $1,25-(\mathrm{OH})_{2} \mathrm{D}_{3}$ to $1,24,25-$ $(\mathrm{OH})_{3} \mathrm{D}_{3}$, and more polar metabolites in exactly the same way as exogenous 1,25$(\mathrm{OH})_{2} \mathrm{D}_{3}$, confirming the hypothesis that fibroblasts are able to regulate the concentration of locally synthesised $1,25-(\mathrm{OH})_{2} \mathrm{D}_{3}$ in vitro.

Our experiments also indicate that a relatively small number of macrophages $(2.18 \times$ $10^{5}$ cells per incubation) have the ability to make a large amount of $1,25-(\mathrm{OH})_{2} \mathrm{D}_{3}$. The concentration of substrate $25-(\mathrm{OH}) \mathrm{D}_{3}$ used in the co-culture system was physiological (12.5 $\mathrm{ng} / \mathrm{ml}$ or $\left.3.125 \times 10^{-8} \mathrm{M}\right)$ and resulted in $1,25-$ $(\mathrm{OH})_{2} \mathrm{D}_{3}$ concentrations of approximately $6 \times$ $10^{-9} \mathrm{M}$ and $1.7 \times 10^{-8} \mathrm{M}$ in control and IFN $\gamma$ stimulated cultures respectively after 24 hours. As the normal serum concentration of 1,25 $(\mathrm{OH})_{2} \mathrm{D}_{3}$ is in the order of $10^{-10} \mathrm{M}$ to $10^{-11} \mathrm{M}$ $\left(20-50 \mathrm{pg} / \mathrm{ml}\right.$; from Mawer et $\left.a l^{19}\right)$, it is theoretically possible that, unless regulated, high concentrations of $1,25-(\mathrm{OH})_{2} \mathrm{D}_{3}$ could be synthesised in the joint within a relatively short time period. The concentration of macrophage derived $1,25-(\mathrm{OH})_{2} \mathrm{D}_{3}$ was reduced to $6 \times 10^{-9}$ $\mathrm{M}$ in the co-culture incubation (24 hour incu- 
bation with $2.18 \times 10^{5}$ macrophages and $1.1 \times$ $10^{5}$ fibroblasts), because of the catabolic effects of the fibroblast 24-OHase. This is one third of the concentration present in the IFN $\gamma$ stimulated macrophages alone, although the regulatory effect of the fibroblasts may depend on the ratio of the different cell types and incubation time. Macrophages and fibroblasts are generally the predominant cell types in the rheumatoid lesion, but their relative proportion and distribution can be highly variable, even within the same specimen. ${ }^{20}{ }^{21}$ We have measured the synovial fluid concentration of $1,25-(\mathrm{OH})_{2} \mathrm{D}_{3}$ in patients with rheumatoid arthritis receiving oral vitamin $\mathrm{D}_{2}$ treatment and shown that concentrations were up to $2.5 \times 10^{-10} \mathrm{M}$ (100 $\mathrm{pg} / \mathrm{ml}$; unpublished results). We did not detect concentrations higher than this in vivo, possibly because of insufficient substrate, inactivated macrophages or local breakdown within the joint in analogous fashion to that which we have described in the co-culture in vitro.

The beneficial effects of $1,25-(\mathrm{OH})_{2} \mathrm{D}_{3}$ in a number of animal models of autoimmunity, including experimental autoimmune encephalitis and autoimmune diabetes, ${ }^{1-3} 22$ have led to the suggestion that $1,25-(\mathrm{OH})_{2} \mathrm{D}_{3}$, or one of its analogues, may be a valuable treatment approach to arthritis. ${ }^{46}$ It would be possible, rather than giving $1,25-(\mathrm{OH})_{2} \mathrm{D}_{3}$, or its analogues, systemically (as was the case for the animal experiments), to inject it locally into the joint, as for corticosteroid treatment, thus targeting the site of inflammation directly. Our findings on the ability of $1,25-(\mathrm{OH})_{2} \mathrm{D}_{3}$ to stimulate its own catabolism within the environment of the synovial joint would be of critical importance in regulating the local concentration of $1,25-(\mathrm{OH})_{2} \mathrm{D}_{3}$ in these circumstances.

Funding: this work was supported by the Arthritis and Rheumatism Council for Research.

1 Lemire JM, Archer DC. 1,25-Dihydroxyvitamin $\mathrm{D}_{3}$ prevents the in vivo induction of murine experimental encephalomyelitis. J Clin Invest 1991;87:1103-7.

2 Mathieu C, Laureys J, Sobis H, Vandeputte $M$, Waer $M$, Bouillon R. 1,25-Dihydroxyvitamin $\mathrm{D}_{3}$ prevents insulitis in Bouillon $\mathrm{R}$. 1,25-Dihydroxyvitamin $\mathrm{D}_{3}$
NOD mice. Diabetes 1992;41:1491-5.

3 Mathieu C, Waer M, Casteels K, Laureys J, Bouillon R. PreMathieu C, Waer M, Casteels K, Laureys J, Bouillon R. Pre-
vention of type I diabetes in NOD mice by nonhypercalcemic doses of a new structural analog of 1,25 dihydroxyvitamin $\mathrm{D}_{3}, \mathrm{KH} 1060$. Endocrinol 1995;136: 866-72

4 Cantorna MT, Hayes CE, DeLuca HF. 1,25Dihydroxycholecalciferol inhibits the progression of arthritis in murine models of human arthritis. J Nutr 1998;128 68-72.
5 Huckins D, Felson DT, Holick M. Treatment of psoriatic arthritis with oral 1,25 -Dihydroxyvitamin $\mathrm{D}_{3}$ : a pilot study. Arthritis Rheum 1990;33:1723-7.

6 Tsuji M, Katsuyuki F, Toshiaki N, Yasuho N. $1 \alpha$ Hydroxyvitamin $\mathrm{D}_{3}$ inhibits type II collagen-induced arthritis in rats. FEBS Lett 1994;337:248-50.

7 Mawer EB, Hayes ME, Still PE, Davies M, Lumb GA, Palit $\mathrm{J}$, et al. Evidence for nonrenal synthesis of 1,25dihydroxyvitamin $\mathrm{D}$ in patients with inflammatory arthritis. J Bone Miner Res 1991;6:733-9.

8 Mawer EB, Hayes ME, Berry JL, Davies M. Extra-renal synthesis of 1,25-dihydroxyvitamin D: Implications in inflammatory arthritis and cancer. In: Norman AW, Bouillon $\mathrm{R}$, Thomasset $\mathrm{M}$, eds. Vitamin D - A pluripotent steroid hormone: structural studies, molecular endocrinology and hormone: structural studies, molecular endocrinology and clinical applications. Proceedings of the Ninth Workshop on
Vitamin D; 1994, May 28-June 2. Orlando (FL). Berlin: Vitamin D; 1994, May 28-June 2.
Walter de Gruyter, 1994:485-93.

9 Hayes ME, Denton J, Freemont AJ, Mawer EB. Synthesis of the active metabolite of vitamin $\mathrm{D}, 1,25(\mathrm{OH})_{2} \mathrm{D}_{3}$, by synovial fluid macrophages in arthritic diseases. Ann Rheum Dis $1989 ; 48: 723-9$.

10 Fowler SJ, Yuan JY, Freemont AJ, Mawer EB, Hayes ME. $1,25(\mathrm{OH})_{2} \mathrm{D}_{3}$ synthesis in synovial fluid macrophages from patients with inflammatory arthritis. In: Norman AW, Bouillon $\mathrm{R}$, Thomasset $\mathrm{M}$, eds. Vitamin $D-A$ pluripotent Bouillon $\mathrm{R}$, Thomasset $\mathrm{M}$, eds. Vitamin $D-A$ pluripotent
steroid hormone: structural studies, molecular endocrinology and clinical applications. Proceedings of the Ninth Workshop on
Vitamin D; 1994, May 28-June 2; Orlando (FL). Berlin: Vitamin D; 1994, May 28-June
Walter de Gruyter, 1994:145-6.

11 Hayes ME, Rai A, Cooper RG, Bayley D, Freemont AJ, Mawer EB. Inhibition by prostaglandin $\mathrm{E}_{1}$ and $\mathrm{E}_{2}$ of 1,25 dihydroxyvitamin $\mathrm{D}_{3}$ synthesis by synovial fluid macrophages from arthritic joints. Ann Rheum Dis 1992;51: 632-7.

12 Hayes ME, Yuan JY, Freemont AJ, Mawer EB. Interferon- $\gamma$ and eicosanoid regulation of 1,25-dihydroxyvitamin $D_{3}$ synthesis in macrophages from inflammatory arthritic joints. Int J Immunotherapy 1994;10:1-9.

13 Hayes ME, Bayley D, Still P, Palit J, Denton J, Freemont AJ, et al. Differential metabolism of 25 -hydroxyvitamin $\mathrm{D}_{3}$ by
cultured synovial fluid macrophages and fibroblast-like cells from patients with arthritis. Ann Rheum Dis 1992;51: 220-6.

14 Yuan JY, Freemont AJ, Mawer EB, Hayes ME. Regulation of $1 \alpha, 25$-dihydroxyvitamin $\mathrm{D}_{3}$ synthesis in macrophages from arthritic joints by phorbol ester, dibutryl-cAMP and calcium ionophore (A23187). FEBS Lett 1992;311:71-4

15 Chen KS, DeLuca HF. Cloning of the human 1 1 , 25dihydroxvitamin D-3 24-hydroxylase gene promotor and identification of two vitamin $\mathrm{D}$ responsive elements. Biochim Biophys Acta 1995;1263:1-9.

16 Holick MF, Kleiner-Bossaller A, Schnoes HK, Kasten PM, Boyle IT, DeLuca HF. 1,24,25-Trihydroxyvitamin $\mathrm{D}_{3}$ : A metabolite of vitamin $\mathrm{D}_{3}$ effective on intestine. J Biol Chem 1973;248:6691-6.

17 Mee AP, Webber DM, May C, Bennett D, Sharpe PT, Anderson DC. Detection of canine distemper virus in bone cells in the metaphyses of distemper-infected dogs. J Bone cells in the metaphyses of diste
Miner Res 1992;7:829-34.

18 Mee AP, Denton J, Hoyland JA, Davies M, Mawer EB. Quantification of vitamin D receptor mRNA in tissue sections demonstrates the relative limitations of in situ-reverse transcriptase-ploymerase chain reaction. J Pathol 1997; 182:22-8.

19 Mawer EB, Berry JL, Cundall JP, Still PE, White A. A sensitive radioimmunoassay using a monoclonal antibody that is equipotent for ercalcitriol and calcitriol (1,25-dihydroxy vitamin $\mathrm{D}_{2}$ and $\mathrm{D}_{3}$ ). Clin Chim Acta 1990;190:199-210.

20 Bromley M, Woolley DE. Histopathology of the rheumatoid lesion: Identification of cell types at sites of cartilage lesion: Identification of cell types at sit

21 Woolley DE, Tetlow LC. Observations on the microenvironmental nature of cartilage degradation in rheumatoid lesion. Ann Rheum Dis 1997;56:151-61.

22 Lemire J. The role of vitamin $\mathrm{D}_{3}$ in immunosuppression: Lessons from autoimmunity and transplantation. In: Feldman D, Glorieux FH, Pike JW, eds. Vitamin D. San Diego: Academic Press, 1997:1167-81. 